\title{
Rethinking State Social Responsibility With the Creation of Shared Public Value
}

\author{
Haroldo de Sá Medeiros ${ }^{1}$ \& Sérgio Henrique Arruda Cavalcante Forte ${ }^{2}$ \\ 1 Campus UNIR, NUCSA, Departamento Acadêmico de Administração, Federal University of Rondônia, \\ PPGA/UNIR, Brazil \\ ${ }^{2}$ University of Fortaleza, PPGA/UNIFOR, Brazil \\ Correspondence: Haroldo de Sá Medeiros, Campus UNIR, NUCSA, Departamento Acadêmico de Administração, \\ Federal University of Rondônia, Porto Velho-RO, Brazil.
}

Received: September 9, 2020

Accepted: December 9, 2020

Online Published: January 10, 2021

doi:10.5430/ijba.v12n1p44

URL: https://doi.org/10.5430/ijba.v12n1p44

\begin{abstract}
Discussions about State Social Responsibility and Public Value are not recent. When linked to each other there is not an incremental theoretical sequence that shows the evolution of responsibility in public organizations. This essay aims to elaborate a framework for public administration, based on the Creating Shared Value (CSV). The use of CSV is justified because it allows the conceptual comparison between public and private perspectives. This framework was called State Creation of Shared Public Value and the operational structure of the CSV was maintained with the levels and the evaluation mechanism, but the original definitions were re-specified for the context of Public Value. The CSV based structure through levels and stages guarantees a gradual increase in the scope of benefits from public services that can be framed in the same perspective, with no restrictions of areas or segments for their use through Public Value.
\end{abstract}

Keywords: state social responsibility, creating shared value, public value

\section{Introduction}

Discussions about Organizational Social Responsibility are not recent. Originated from the perspective of private organizations, it maintained the initial focus directed only at economic and legal responsibilities, as described by Friedman (1970). Subsequently, it was influenced by stakeholder theory and gained broader approaches to corporate Social responsibility, broadening organizational responsibilities with ethical and philanthropic dimensions (Carroll 1991).

In the 1980s, Wartick and Cochran (1985) proposed a framework using the four dimensions of Carroll (1991) to operationalize the corporate social responsibility, relating it to organizational principles, processes and policies. It was later expanded by the literature on business strategy and competitive advantage through the work of Porter and Kramer (2002, 2006). It was added to other concepts such as sustainability, the value chain and clusters and had its initial conception of generation of modified value with the shared value creation management model by Porter and Kramer (2011). In this model, the value generated by social responsibility actions ceases to be only economic, becoming economical, social and environmental, as well as being strategically linked to the core business of companies.

In contrast, within public organizations there is no clear sequence of definitions. From the initial concept of basic state responsibility, which is social protection, no tool, theory or managerial model was generated and the social responsibility of public organizations, sometimes called State Social Responsibility (SSR), did not develop related to governmental strategies (Lombardo \& D'orio, 2012). The influence of stakeholder theory on SSR does not encompass more direct forms of interaction of society or interest groups in public decision-making processes, restricting itself to the dissemination of information through e-government projects (Gupta, 2016). In addition, the creation of value, called PV, developed with characteristics inherent to the elaboration of public policies, disregarding more practical elements of management (Mintrom \& Luetjens, 2015).

There is no succession of incremental and conceptual links in the development of managerial knowledge on social responsibility of public organizations. The generation of isolated ideas stands out, with a disconnection in the addition of new meanings, in which the public strategies are not linked to the responsibility of the public institutions and the PV 
is not considered a result of the SSR. Therefore, it is proposed that this conceptual gap be filled and that the development of managerial knowledge about the public sector be equated with that of private organizations.

Thus, in seeking to answer "how can SSR be reestablished from a managerial perspective?", It is proposed to elaborate a framework for public administration, based on the Creation of Shared Value. The use of CSV is justified because it is the most recent model that deals with social responsibility, allowing the conceptual comparison between public and private perspectives.

In order to achieve the proposed objective, a theoretical essay was developed to discuss the possibilities of the public sector to create shared value through the operational definitions that involve the CSV, including the framework and its applications. As a methodology, a bibliographical research was carried out on the themes involving CSV, PV and SSR in national and international journals.

Among the terms used in this study, the public sector, public management and the State stand out. There is no objective to distinguish them using legal bases, however, it is understood that all describe the set of governmental organizations that form the Direct and Indirect Public Administration.

This article presents social and theoretical relevance. For the social sphere, when proposing the elaboration of a framework for public administration based on the Creation of Shared Value, it is believed that the analyzes carried out can provide information so that governmental actions create PV and benefit groups in situations of vulnerability. These benefits derive from a responsive administration, which has ethics as the basic principle of the management of public resources and that directs strategically the planning of public policies. Thus, it is believed that the concepts linked to the CSV can be re-specified from the perspective of governmental organizations and that their use can contribute to the generation of a conceptual framework in the managerial theorizing about SSR. These contributions can broaden the state of the art on public management, mainly because it considers elements that have been elaborated for private organizations, but which distance themselves from New Public Management and public governance through their democratic nature.

\section{Creating Shared Value (CSV)}

Originally focused on the perspective of private organizations, the CSV is a set of operational policies and practices that increases the competitiveness of a company and simultaneously contributes to the strengthening of economic and social conditions in the communities where it operates (Kramer \& Pfitzer, 2016; Kramer, 2011).

Initially, the CSV was composed only of concepts widely distributed in the management field, such as the formation of Clusters, the Value Chain and Sustainability. Subsequently, it was expanded in the work of Porter et al. (2011) and Kramer and Pfitzer (2016) with the inclusion of shared value creation mechanisms and discussions about their Collective Impact, respectively.

In CSV, values arise from the connection between economic-financial value and social progress. This connection results from business that generate benefits in order to solve negative externalities that have been caused over time by public neglect or by the action of private organizations, such as poverty, inequality, hunger, pollution, among others (Porter \& Kramer, 2011; Wójcik, 2016).

From an operational perspective, shared value creation occurs at three levels: (1) re-evaluation of products and markets; (2) redefinition of productivity in the value chain and (3) support for the development of local clusters (Porter \& Kramer 2011; Porter et al., 2012), as can be seen in Table 1.

Table 1. Levels of value creation

\begin{tabular}{|c|c|c|c|}
\hline $\begin{array}{l}\text { Levels of value } \\
\text { creation }\end{array}$ & Goal & Results for the business & Results for society \\
\hline $\begin{array}{l}\text { Revaluation of } \\
\text { products and } \\
\text { markets }\end{array}$ & $\begin{array}{l}\text { Identify the needs of society to } \\
\text { transform them into business } \\
\text { opportunities, incorporating } \\
\text { their aspects into the products } \\
\text { and forms of distribution. }\end{array}$ & $\begin{array}{l}\text { Increase in revenue; increase } \\
\text { in market share and growth } \\
\text { levels; improving } \\
\text { profitability. }\end{array}$ & $\begin{array}{l}\text { Improvement in medical } \\
\text { care; reduction of carbon } \\
\text { emissions; } r \text { improving } \\
\text { nutritional or educational } \\
\text { status. }\end{array}$ \\
\hline $\begin{array}{l}\text { Redefinition in } \\
\text { the value chain }\end{array}$ & $\begin{array}{l}\text { Better manage internal } \\
\text { operations to increase } \\
\text { productivity and reduce risk. }\end{array}$ & $\begin{array}{l}\text { Productivity increase; } \\
\text { reduction of logistical and } \\
\text { operational costs; guarantee }\end{array}$ & $\begin{array}{l}\text { Reduction of energy and } \\
\text { water use; reduction of the } \\
\text { use of inputs; improving }\end{array}$ \\
\hline
\end{tabular}




\begin{tabular}{|c|c|c|c|}
\hline & & $\begin{array}{lr}\text { of supply; } & \text { increase in } \\
\text { quality; } & \text { improving } \\
\text { profitability. } & \end{array}$ & $\begin{array}{l}\text { skills and remuneration of } \\
\text { the workforce. }\end{array}$ \\
\hline $\begin{array}{l}\text { Support for the } \\
\text { development of } \\
\text { local clusters }\end{array}$ & $\begin{array}{l}\text { Modifying the external } \\
\text { environment of the } \\
\text { organization to provide growth } \\
\text { and productivity gains. }\end{array}$ & 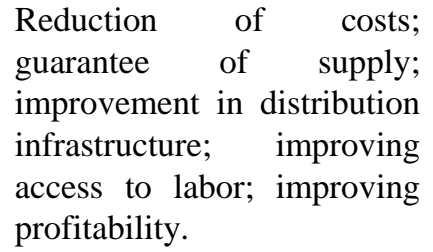 & $\begin{array}{l}\text { Increased labor supply; } \\
\text { improvement in educational } \\
\text { and health services; increase } \\
\text { in economic gains. }\end{array}$ \\
\hline
\end{tabular}

Source: Adapted by the authors from Porter \& Kramer (2011) and Porter et al. (2012).

The identification of the needs of society and their transformation into business opportunities had already been described by Prahalad and Hart (2002) when they dealt with the development of new products and services aimed at markets with low income public in developing countries. Both Prahalad and Hart (2002) and Porter and Kramer (2011) consider that the market is changeable and that the identification of needs as opportunities would provide a repositioning of companies in relation to traditional markets. In addition, it could foster knowledge of new markets that were not seen as promising. Thus, the re-evaluation of products and markets is a process that generates a new conception of products and new forms of distribution, opening spaces for innovations.

The redefinition of productivity in the value chain focuses on the management of seven strategic elements: energy, logistics, inputs and raw materials, forms of purchase, distribution, employee productivity and location (Porter \& Kramer, 2011; Porter et al. 2012). All these elements, if poorly managed, can cause negative social and environmental impacts. From the perspective of CSV, the redefinition of productivity in the value chain would have characteristics related to sustainability, having as central idea the adjustments in operations, from the acquisition of inputs to the distribution of products, favoring savings and the supply of raw materials from companies with environmental certificates to create shared value. In this way, organizations would reduce externalities by increasing product quality, maximizing production efficiency, and reducing their costs from the payment of fees or fines for the use of inputs that are harmful to the environment.

The third level of CSV is the support for the development of clusters. It is important to highlight that this perspective of interaction of companies with local suppliers, promoting local economy and development is not recent (Crane et al. 2014), with Porter (1998) published on the subject. The existence of clusters is a preponderant factor for the development of regional economies, with the function of stimulating the productivity and efficiency of micro and small producers, fomenting local entrepreneurship and the creation of jobs, even through ancillary services. It stands out as a positive aspect of the creation and support of clusters in the formation of fair and transparent markets. In this type of market, there is assurance of the purchase of inputs and the confidence in the supply, elements that can promote the quality and productive efficiency, as well as substantially increase the income and purchasing power of the local population (Porter \& Kramer, 2011).

The principle of CSV levels can be understood as a cumulative set of steps (Porter \& Kramer, 2011; Porter et al., 2012). That is, as a company moves up the levels, it creates and shares more value. The support to the development of local clusters could not be realized without the redefinition in the value chain that adds value to the products, and this could not be done without the revaluation of products and markets. In this way, it would not be possible to reach a level without going through the previous one.

In addition to the levels, the other two elements that constitute the main characteristics of the CSV are the shared value evaluation mechanism and the Collective Impact of organizational actions.

The valuation of shared value requires an interactive process that is integrated into the business strategy and must be linked to the measurement of business performance. The mechanism, according to Porter et al. (2012), is a qualitative model divided into four stages: (1) Identify the target question, (2) Make the case of the business, (3) monitor the progress and (4) evaluate the results and use the knowledge to discover new values, As can be seen in Figure 1. 


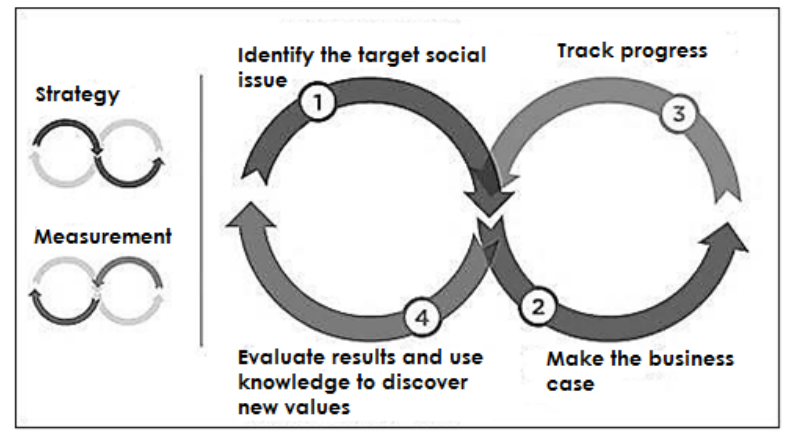

Figure 1. Integrated shared value strategy and measurement

Source: Porter et al. (2012).

First step: Identify the target social issue. The starting point for shared value is to identify and prioritize specific social issues that represent opportunities to increase revenue or reduce costs. This requires systematic screening of unmet social needs and gaps and an analysis of how they overlap the business across all three levels of shared value. The result of this step is a list of priority social issues targeting a shared value strategy.

Step Two: Make Business Case. After identifying the impact of social potential on one or more of the three levels of shared value, the next step is to develop a solid business case based on research and analysis of how a social improvement can directly develop business performance. This step includes identifying the targets and specifying the activities and costs involved for each shared value opportunity, modeling business potential and social outcomes against costs and making decisions to go or not with each action.

Step Three: Track progress. Using the business case as a roadmap, companies track their progress toward reaching the desired targets, as with any process of improvement and development. This step includes monitoring inputs and outputs, as well as financial performance in relation to projections made.

Step Four: Evaluate results and use knowledge to discover new values. The final step is to validate the link between social and business results and determine whether the investment of corporate resources and efforts produced generated a good common return. When focusing on shared value principles, it is important to emphasize that the choices made should benefit both society and shareholders, since pursuing policies and actions that benefit only one party to the detriment of the other can lead to negative social and environmental repercussions (Alberti \& Belfanti, 2019).

Collective Impact results from the creation and development of coordinated stakeholder strategies (Gwynne et al., 2016, Kania \& Kramer, 2013). Its focus is on the joint search of organizations for resources, the promotion of innovations through congruent goals, the establishment of continuous feedback and learning links (Hanleybrown, Kania \& Kramer 2012).

In order for there to be Collective Impact, five conditions are necessary: (1) generation of a common agenda of objectives, problems and actions among stakeholders, (2) shared evaluation of information and results of joint efforts to maintain alignment between the responsibilities of each stakeholder, (3) Mutual reinforcement of activities through a plan of action, (4) creation of continuous communication mechanisms and (5) creation of a support team with specific competencies to manage and coordinate joint actions (Gwynne et al., 2016; Hanleybrown, Kania \& Kramer, 2012; Kania \& Kramer, 2013).

When related to CSV, the Collective Impact is based on the idea that social problems arise and persist due to a complex combination of actions and omissions of organizations from all sectors. Therefore, they can only be resolved by coordinated efforts between companies, government, non-governmental organizations, members of affected populations or any other stakeholders, this kind of joint effort would change the functioning of a system of errors and Would create what is called the "Shared value ecosystem" (Kramer \& Pfitzer, 2016). Also, when related to the levels of CSV, the Collective Impact presupposes the existence of support for the development of local clusters, associating more to the third level, so that the ecosystem becomes an environment of cooperation and that allows to provoke real changes in Socially and environmentally harmful conducts, in addition to economically benefiting companies and communities (Kramer \& Pfitzer, 2016). 
Although CSV is an important building of ideas that makes operational some managerial concepts, it also has its limitations. In fact, it cannot be regarded as a new organizational paradigm, as presented by Porter and Kramer (2011), as it presents a set of characteristics consisting of increments of other theoretical frameworks originated from sustainability or organizational strategies (Medeiros et al., 2016).

Identifying the needs of society, the first level of creation and sharing of value, does not distance itself from the economic needs of organizations. The idea of a for-profit organization overlapping its social and economic functions is naive, for there is no way to think of it within the traditional capitalist logic. The provision of products that provide benefits to consumers without damaging the planet, or even providing benefits to local communities, is significant and significant, but the very production and maintenance of clusters would depend on the proper functioning of organizations' financial issues. In this way, the social and environmental dimensions would be dependent on the economic one, not having a significant rupture with the corporate social responsibility logic (Crane et al., 2014).

\section{CSV in the Public Sector: Is It Possible?}

The elaboration of a managerial framework for the public sector that uses the CSV can lead to the following question: Is the state able to create shared value? However, to answer this question, some concepts need to be discussed.

The organizational social responsibility does not present a well-defined evolution in the public sphere, however there are some conceptual equivalences in relation to the private one (Lombardo \& D'orio, 2012), being possible to visualize them in Figure 2. Thus, for the State, the protection social is the origin of responsibility, followed by SSR, while the PV would be the most recent concept, even if it is not derived from previous ones.

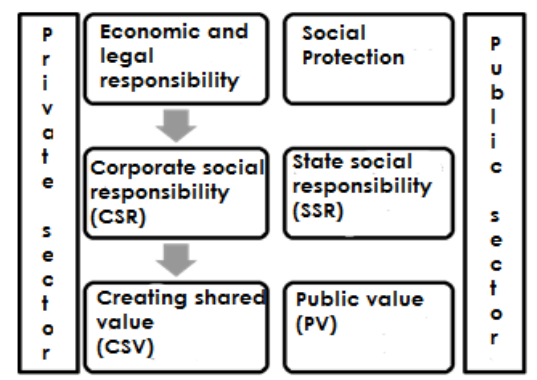

Figure 2. Organizational social responsibility of the private and public sectors

Source: Prepared by the authors (2019).

By definition, social protection is understood as the maintenance of the basic rights of the population and aims to minimize vulnerability through health, education, security, among other areas (Lombardo \& D'orio, 2012). Among its characteristics, ethics stands out as the basis for the elaboration and direction of public policies, as well as for the allocation of the financial resources tied to their execution (Plagerson \& Ulriksen, 2016; Ulriksen \& Plagerson, 2016).

SSR is a complement to social protection, occurring as proactive public administration behavior, supported by legal norms, to mitigate negative externalities that affect society. It is formed by a set of actions that meet the demands for social services, considering the need to redefine the way in which the State relates to citizens and its leadership role in relation to other forms of organization. SSR actions should be informative in nature, showing the population about the origins of these externalities to help protect current and future generations (Lombardo and D'orio, 2012).

An important feature of SSR is also the ethical principle of public actions, since there is a voluntary implication of the responsibility of public managers that goes beyond legal obligations, but without challenging those (Fonseca \& Jebaseelan, 2017). Instead of public managers being engaged in electoral possibilities with short-term proposals and providing training and lobbying, they must take long-term measures to minimize negative externalities (Lombardo \& D'orio, 2012). Thus, they could create and deliver public policies that meet real social needs with objective responsibility, strengthening public administration and legitimizing their actions. Another highlight is the non-strategic nature of SSR. This is due to the exclusion of public organizations in the elaboration of specific models of strategic management. However, public management can be related to traditional concepts of strategy, with result orientation (Johanson, Pekkola \& Husman 2016). 
PV has its origins in Moore's (1994) work and has become popular in discussions on strategy in public management. Since then, it has been related to other themes, including strategic management of public organizations, stakeholder theory, value chain and sustainability, but its development is not related to SSR, since it is not strategic in nature.

$\mathrm{PV}$ is defined as the results of increased efficiency and effectiveness that are delivered to citizens from government action (Mintrom \& Luetjens, 2015; Moore, 1994). That is, to the extent that the public administration strategically chooses which public policies to create and deliver them so that their effects bring real benefits to society, there is a positive result with generation of $\mathrm{PV}$.

The process of generating PV follows the common systemic perspective, with inputs, processing, output and measurable outcomes (Bryson, Crosby \& Bloomberg 2014). Some authors such as Alberto (2013), Al-Raisi and Al-Khouri (2010) and Dumay (2014) described these processes for specific segments, calling them the PV Chain and adapting them to different realities. According to Loeffler \& Bovaird (2019), even risks associated to the PV chain could be considered in public value generation systemic approach.

The PV Chain is the description of a set of procedures in which there is added value through State action. These actions may be exclusive to the public administration or may involve partnerships with other types of organizations in coproducing public services. The importance of this description lies in enabling the verification of where the value is being destroyed or stagnating, allowing review and replanning (Benington \& Moore, 2011).

Another important point in this discussion is the State's search for the legitimization of its actions, involving the management of stakeholders and the role of public leadership. As far as leadership is concerned, the generation of LVs results from public managers developing public policies that ensure the public interest (Benington \& Moore, 2011). This requires that public policies are aligned with the interests of stakeholders, involving them with integrated forms of participation and building on their experiences (Mintrom \& Luetjens, 2015).

The democratic and inclusive character of stakeholder participation would be the characteristic that would influence the legitimacy of state actions, making sure that the public interest is actually met and reducing the possibility of electoral opportunism. From this, the creation of PV can be related to ethics, since the rational nature of the creation of public policies would generate a political environment stimulated by the ethical behavior of the public managers, favoring the sharing of the created values (Sami et al., 2015).

Although the literature does not relate the PV to social protection and SSR, some attributes are common to the three concepts, and can be understood as presuppositions for the generation of new ideas based on public social responsibility, as can be seen in Figure 3. In this way, the first assumption is that ethics is basic to the state as an important element to direct and legitimize its actions.

Similarly, other characteristics can be associated with each other by having similarities, such as sustainability with reducing vulnerability and providing information to stakeholders with their involvement in the elaboration of public policies.

Due to the complementarity between social protection and SSR, both would form a single step in the evolution of organizational social responsibility, because their definitions do not imply the disuse or exclusion of the older concept in relation to the younger one. Neither is it verified that one covers the characteristics of the other through the addition of new responsibilities to the State.

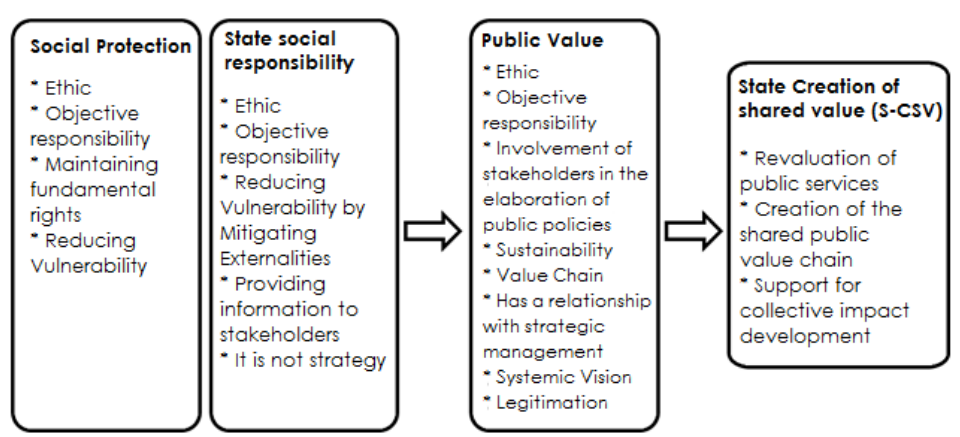

Figure 3. Conceptual connections and RSO characteristics in the public sector

Source: Prepared by the authors (2019). 
On the other hand, the characteristics of the PV cover those existing in social protection and SSR, in addition to adding new responsibilities to the State. In this case, the promotion of sustainability is a way of maintaining the fundamental rights (Santos, 2017; Takhar, 2015; Tzagkarakis et al., 2017) and vulnerability reduction (Ezeibe, Oguonu, Ajaero, Osadebe, Agbo \& Uwaechia, 2019), while the involvement of stakeholders in the elaboration of public policies also has the function of providing information (Benington, Mintrom \& Luetjens, 2015, Moore, 2011).

This scope, followed by the maintenance of the State's objective responsibility and ethics in state actions, would form the conceptual connections. While the inclusion of other characteristics, such as those resulting from strategic management, the systemic vision and the search for legitimation, would imply new responsibilities for the public sector, constituting itself as a new stage of organizational social responsibility.

The similarities between social protection, SSR and PV or even their cumulative nature would provide the information of two other assumptions that should guide the elaboration of S-CSV. The second assumption is characterized by the use of sustainability as principles in the elaboration of public policies, while the third assumption deals with the democratic involvement of stakeholders in public actions.

The only feature that is not common or similar to the three concepts is the Public Value Chain (PVC), which is unique to PV. However, when comparing its definition with that of CSV, there is a restriction on the delivery of the value. As can be seen in the works by Alberto (2013), Al-Raisi and Al-Khouri (2010) and Benington and Moore (2011), PVC still use Porter's (1991) definition, in which value is end of all procedures and addition steps, while in the more recent works by Porter and Kramer (2011) and Porter et al. (2012) the value can be delivered in all steps and procedures of the chain.

This restriction implies a significant limitation of PV in relation to CSV, since there is no sharing of values that do not derive from a complete delivery of public policies, reducing the positive effects of government actions and making stakeholder involvement less participatory.

From this, it is inferred that the necessity of equating the public and private models, besides theoretical and conceptual, also part of this managerial aspect, whose value delivery could not be limited to the end of the chain. By proposing the S-CSV, which can be seen in Figure 2, it is also proposed the establishment of a new milestone of the organizational social responsibility for the public sector with the objective of creating and sharing PV in the various stages and procedures of the chain of PV.

Considering that S-CSV uses the CSV as a basis for conceptual equalization among the different sectors, the next section of this paper describes the main definitions and characteristics related to the private model, so that there is the necessary understanding of the development of the public framework in sections posterior.

\section{State Creation of Shared Public Value (S-CSV)}

The concepts presented and discussed previously support the proposal of elaboration of the managerial framework for the sector, being this section dedicated to its development. However, before presenting it, it is necessary to answer a question: considering the nature of the CSV and the PV, it is possible to intercept between models that deliver different values?

Although the notion of CSV value derives from relations between economic benefits and social progress, while the one derived from the PV are social benefits derived from public efficiency, the combination used the operation of the private model to make the public applicable, not considering a cross of values, but adaptations and substitutions for the framework generation. Therefore, the operational structure of the CSV was maintained with the levels and the evaluation mechanism, but the original definitions were re-specified for the context in which they were intended. Thus, the social and economic values were modified for the PV and the value chain was changed to a PVC model that also covers the valuation of the shared value.

Initially, the framework was called the Shared Public Value State Creation (S-CSV), as it can be seen in Figure 2. Its objective is to allow government actions to create shared PV and benefit a broad group of stakeholders because they are in a situation of vulnerability. These benefits derive from a responsive administration, which has ethics as the basic principle of the management of public resources and that directs strategically the planning of public policies.

To meet your goal, the framework has built-in definitions. The first definition consists of the levels of S-CSV, being: (1) reassessment of public services; (2) creation of the shared PV chain; and (3) support to the development of CI. The levels also form a cumulative set of steps, just as in CSV. By advancing at levels, public administration creates more shared PV and benefits a greater number of stakeholders. Table 2 shows the re-specified levels, their objectives, the expected results for society and the authors that base the definitions. 
Table 2. Levels of S-CSV

\begin{tabular}{|c|c|c|c|}
\hline $\begin{array}{l}\text { Levels of value } \\
\text { creation }\end{array}$ & Goals & Results for society & Authors \\
\hline $\begin{array}{l}\text { 1st level: } \\
\text { Revaluation of } \\
\text { public services }\end{array}$ & $\begin{array}{l}\text { Create public services } \\
\text { strategically oriented to the } \\
\text { needs and expectations of } \\
\text { users and the community; } \\
\text { promote public engagement } \\
\text { through } \\
\text { mechanisms. }\end{array}$ & $\begin{array}{l}\text { Decrease in the gap between } \\
\text { the nature of public services } \\
\text { and the real needs of the } \\
\text { community; effective } \\
\text { participation of the } \\
\text { population in providing } \\
\text { information; co-creation. }\end{array}$ & $\begin{array}{l}\text { Alford (2016); Alford (2017); } \\
\text { Hiedemann, Nasi and } \\
\text { Saporito (2017); Osborne et } \\
\text { al. (2014); Osborne et al. } \\
\text { (2015); Osborne, Radnor and } \\
\text { Nasi (2012). }\end{array}$ \\
\hline $\begin{array}{l}\text { 2nd level: } \\
\text { Creation of the } \\
\text { shared public } \\
\text { value chain }\end{array}$ & $\begin{array}{l}\text { Identify the stages of creation } \\
\text { of the PV in the elaboration } \\
\text { and implementation of public } \\
\text { services and policies; identify } \\
\text { the activities and processes of } \\
\text { the chain that can be } \\
\text { coproduced by the } \\
\text { stakeholders; improve the } \\
\text { quality of public services; } \\
\text { improve public confidence in } \\
\text { public institutions. }\end{array}$ & $\begin{array}{l}\text { Value sharing at all stages of } \\
\text { the chain; increasing the } \\
\text { delivery of the positive } \\
\text { effects resulting from public } \\
\text { services and policies; } \\
\text { legitimacy of government } \\
\text { actions. }\end{array}$ & $\begin{array}{l}\text { Al-Raisi and Al-Khouri } \\
\text { (2010); Benington and Moore } \\
\text { (2005); Bryson, Crosby and } \\
\text { Bloomberg (2014); Dumay } \\
\text { (2014); Moore (2007); Moore } \\
\text { (2014); Sotelo Maciel (2012). }\end{array}$ \\
\hline $\begin{array}{l}\text { 3rd level: } \\
\text { Support for } \\
\text { collective } \\
\text { impact } \\
\text { development }\end{array}$ & $\begin{array}{l}\text { Integrate diverse public } \\
\text { organizations to make them } \\
\text { focused on the analysis and } \\
\text { resolution of specific } \\
\text { problems; assess the collective } \\
\text { impact based on broad results. }\end{array}$ & $\begin{array}{l}\text { Creation of a shared value } \\
\text { ecosystem. }\end{array}$ & $\begin{array}{l}\text { Carman (2015); Ferber and } \\
\text { White (2014); Gwynne et al. } \\
\text { (2016); Hanleybrown, Kania } \\
\text { and Kramer (2012); Kania } \\
\text { and Kramer (2011); Kramer } \\
\text { and Pfitzer (2016). }\end{array}$ \\
\hline
\end{tabular}

Source: Prepared by the authors (2019).

The first level focuses on the creation of services that actually relate to the real needs of communities and with the extinction of the reasons that cause the maintenance of vulnerability, making public planning more responsive with stakeholder participation.

The revaluation of public services starts from the rupture with the premises of the New Public Management and meets the propositions of Osborne, Osborne et al. (2014), Osborne et al. (2015) and Radnor and Nasi (2012). In this way, they would not only involve an organization, they should be understood as systems that depend on the building of relationships, innovate to become more efficient and effective and their sustainability stems from the transformation of user knowledge and professionalism in their delivery.

One important point is coproduction as an aspect to be considered in the elaboration of public services. Although it is treated by Osborne et al. (2014) and Osborne et al. (2015) as a strict characteristic, and its application can be seen in the work of Hidemann, Nasi and Saporito (2017), which in this work is understood as optional, covering broader aspects of interaction between people and processes in the provision of services, as the provisions of Alford (2016) and Alford (2017).

This choice is justified in the fact that some services need specialized knowledge to be produced and stakeholders may not have it. However, this cannot be a reason that fully limits the possibility of people's participation, such as providing information.

The second level, the creation of the shared PV chain, maintains the systemic dynamics presented by Bryson, Crosby and Bloomberg (2014) and Moore (1994). However, as can be seen in Figure 4, the creation of value does not only result from the provision of public services, but is differentiated from Al-Raisi and Al-Khouri (2010), Benington and Moore (2005), Dumay (2014), Hartley, Parker and Beashel (2019), Moore (2012), Moore (2007) and Sotelo Maciel (2012). 


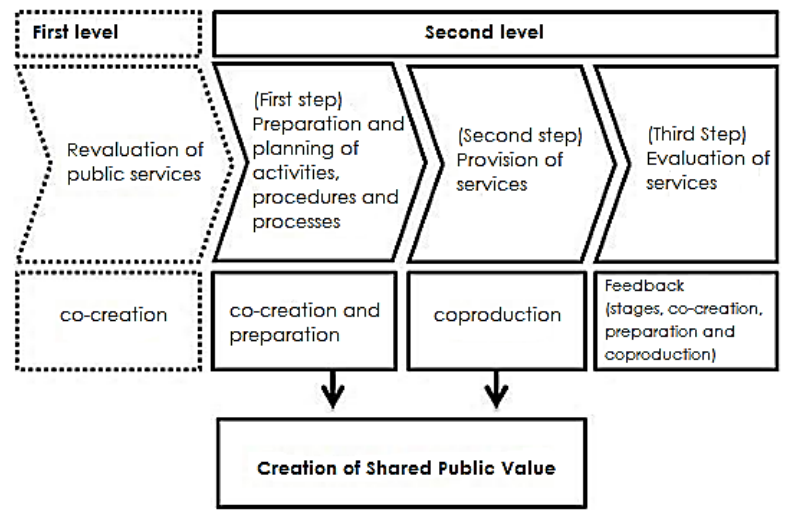

Figure 4. Shared public value chain for the public sector

Source: Elaborated from Dumay (2014) and Benington and Moore (2011).

The main characteristics that make this PVC different from the other PV chains are the forms of interaction of the stakeholders with the elaboration and provision of the services, being these realized through the co-generation and co-production.

Co-creation, besides being a joint creation, corresponds to the generation of value from interactions and the establishment of a relationship between different actors (Grönroos, 2011). In the case of S-CSV, co-creation occurs from the interactions between society and public administration to generate PV in public services. It is present in the first stage of the chain in the preparation and planning of activities, procedures and processes, prior to the provision of services. However, unlike the level of reassessment of public services, it is indispensable in the first stage of the second level and is intrinsically linked to the preparation of society and public administration for the next stage. To the extent that planning happens and some type of elaboration is required, there is a preparation that precedes the production, so that new knowledge can be acquired, the infrastructure needed for the service can be built, people from the community can be employed, among others actions that imply the creation of shared PV.

Co-production involves joint production of policies, actions and services by various actors, provided that it is in the public interest enabling links to create strategies for the efficient, effective and effective provision of services and public goods to citizens (Martins, Lunkes, Mendes \& Ckagnazaroff, 2020). Its objectives are to improve the quality of services by using users' user experience and the involvement of stakeholders in the management of services, so that there is a control of society in the outputs of the chain (Osborne \& Strokosch, 2013). Being present in the second stage of the chain, co-production takes place after co-creation and preparation, characterized by the joint production of services between State, society and other stakeholders, when necessary. Their joint purpose is to execute and control activities in a democratic, efficient and effective manner.

The third step is equivalent to the CSV evaluation mechanisms. It is based on Moore (2007) and was called service evaluation, comprising four procedures: (1) evaluation of activities, procedures and processes by measuring performance, workloads and productivity monitoring through indicators; (2) evaluation of efficiency and effectiveness through measurement of outputs; (3) evaluation of social benefits through the use of social indicators and qualitative instruments and (4) evaluation of the satisfaction of all stakeholders involved in the stages of the chain with emphasis on users of services rendered.

Third-level support for CI development, S-CSV, is the public administration effort to create the conditions for a broad set of organizations to solve specific social problems and to evaluate their results from similar and comparable metrics. These conditions may derive from programs, projects or other actions of the public administration intended to serve regions or large groups of individuals in situations of vulnerability.

Similar to the private CSV perspective, the development of the third level also depends on the five conditions for the CI described by Gwynne et al. (2016), Hanleybrown, Kania and Kramer (2012) and Kania and Kramer (2013) and which were presented in the previous section. Since S-CSV is based on the rescue of objective State responsibility, the formation of clusters to generate private economic benefits through corporate social responsibility is not its guideline. However, partnerships with private organizations can be made, provided that through coordination of public administration. 
In addition to presenting a theoretical proposition with some cumulative elements, the managerial importance of S-CSV lies in the systemic and sequential perspective of co-creation and coproduction, distinguishing itself from previous models and propositions, either for private or public organizations.

The combination of co-creation and co-production in the same value chain provides the delivery of PV in all stages of the elaboration of a service or of a public policy in general, and this is accompanied by the different involvement of public stakeholders. the final step of the chain. In this way, S-CSV can generate an ecosystem of shared PV to combat State conduits that are socially, environmentally and economically harmful to society.

\section{Applications of S-CSV}

S-CSV applications are related to the reduction of vulnerabilities, especially those caused by externalities. The CSV-based structure through levels and stages guarantees a gradual increase in the scope of benefits from public services or other policies that can be framed in the same perspective, with no restrictions of areas or segments for their use.

The first level, revaluation of public services, is directed to actions of lesser scope and intended for small groups of individuals in vulnerable situations. The participation of society through co-creation allows a democratic involvement among stakeholders and does not limit the performance of those who are not from the public administration only to report their real needs for the creation of PV, but involves them in Joint creation of solutions and the evaluation of services.

Actions related to the first level can be seen in the works of Hänninen (2012), Hiedemann, Nasi and Saporito (2017) and Uppström (2014). Even in interactions with small groups, dialogue networks are formed to accomplish collaborations. In some cases, stakeholders may be invited to collaborate with the solution of problems that do not directly affect them, but because they possess competencies for such (Hännien, 2012). The formation of these dialogue networks aims to capture the non-monetary values necessary for policies, activities and public services that will result in the creation of PV (Hännien, 2012; Uppström,, 2014). Todo o processo de criação deste nível torna possível a geração de impactos concretos na satisfação dos participantes e na cultura de colaboração da sociedade (Hiedemann, Nasi \& Saporito 2017).

The second level, creation of the shared PV chain, expands the generation of PV by increasing the number of stakeholders involved in co-creation and preparation, as well as in the co-production of public services. Its systemic characteristic allows the actions of the chain to be organized among the actors, from the elaboration and planning, providing the service to the evaluation. However, this last stage of the chain is the least similar to the characteristics of the evaluation of the CSV, but this is justified by the low condition of empirical development of the provisions of Porter et al. (2012) and the PV does not have a manufacturing essence.

Actions with distinct models of PV chain can be seen in the works of Alford and Yates (2014), Dumay (2014) and Sotelo Maciel (2012). The second level comprises the formation of a public production network, being more complex than the network of the previous level by presenting PV creation in the three stages that compose it (Sotelo Maciel, 2012). By incorporating the dynamics of a chain of activities, it seeks to promote congruence among stakeholders, especially with regard to the objectives that must be achieved for the creation of PV (Alford \& Yates, 2014). However, the chaining also promotes the possibility of mapping processes and their responsible, allowing the identification of participants who do not act well or possible failures in the integration of the network (Dumay, 2014).

The third level, support for the development of the CI, expands the execution of public services to a regional reach, thus creating a shared PV ecosystem through the involvement of various organizations and communities around the Solution to a specific problem. By covering the characteristics of the previous levels, co-creation, preparation and co-production allow adaptations to be made in line with the reality of each site.

The expansion proposed by the third level can be seen as an example in the health programs analyzed by Carman (2015) and Gwynne et al. (2016). Both determine the conditions necessary for HF, described by Gwynne et al. (2016), Hanleybrown, Kania and Kramer (2012) and Kania and Kramer (2013),

Considering that the shared assessment depends on contractual aspects and that mutual reinforcement depends on financing Differentiated for each project to adapt to the conditions of each locality.

\section{Considerations}

In seeking to answer "how can SSR be reestablished from a management perspective?", A theoretical essay was used to generate the S-CSV framework to address the research problem. The implementation of the revaluation of public services, the creation of the shared PV chain, and support for the development of CI comprises an effort of collective 
actions to generate PVs in a shared way through public services, regardless of the area or segment. Similarly, other public policies that do not relate to services may also take precedence over the definitions and structure generated in this article.

Although S-CSV has as its prerogative the redemption of the objective responsibility of the State, it is not possible to affirm that its use is restricted only to neoliberal socioeconomic organizations at national or regional level that seek to legitimize its actions. Therefore, when considering that one of its objectives is the reduction of social vulnerability, localities that are organized socio-economically in other bases can also use their definitions.

Other points to be discussed are the limitations of the propositions performed here. The execution of actions from a framework of this nature depends on the establishment of a friendly relationship between public administration and society, because dialogue and responsive policies do not depart from disagreements. However, there is no need to expect cooperation without exhaustion between stakeholders and that there are no conflicts of interest over time. Thus, in order to remedy these difficulties, conflict mediation instruments can be employed. Or, leaders can be used for a democratic and collaborative environment to be built and maintained.

It is believed that other studies can be performed to test the S-CSV framework and to increment it with other definitions that lead the discussion about PV to a more practical and managerial level. Also, it is hoped that the entire discussion that precedes the structuring of the framework, involving the SSR, can be reinforced with other epistemological bases, encompassing criticisms and new relationships between the concepts.

\section{References}

Alberti, F. G., \& Belfanti, F. (2019). Creating shared value and clusters. Competitiveness Review: An International Business Jornal, 29(1), 39-60. https://doi.org/10.1108/CR-01-2017-0008

Alberto, P. (2013). An innovative public value chain to improve public services. International Journal of Advances in Management and Economics, 2(5), 85-94.

Alford, J. (2016). Co-production, interdependence and publicness: Extending public service-dominant logic. Public Management Review, 18(5), 673-691. https://doi.org/10.1080/14719037.2015.1111659

Alford, J. (2017). Citizen co-production of public services. In T. R. Klassen, D. Cepiku, \& T. J. Lah (Eds.), The routledge handbook of global public policy and administration (pp. 157-166).

Alford, J., \& Yates, S. (2014). Mapping public value processes. International Journal of Public Sector Management, 27(4), 334-352. https://doi.org/10.1108/IJPSM-04-2013-0054

Al-Raisi, A. N., \& Al-Khouri, A. M. (2010). Public value and ROI in the government sector. Advances in Management, 3(2), 33-38.

Benington, J., \& Moore, M. H. (2011). Public value in complex and changing times. Public Value: Theory and Practice, 1-30. https://doi.org/10.1007/978-0-230-36431-8_1

Bryson, J. M., Crosby, B. C., \& Bloomberg, L. (2014). Public value governance: Moving beyond traditional public administration and the new public management. Public Administration Review, 74(4), 445-456. https://doi.org/10.1111/puar.12238

Carman, A. L. (2015). CI through public health and academic partnerships: a Kentucky public health accreditation readiness example. Frontiers in Public Health, 3(44), 1-5. https://doi.org/10.3389/fpubh.2015.00044

Carroll, A. B. (1991). The pyramid of corporate social responsibility: Toward the moral management of organizational stakeholders. Business Horizons, 34(4), 39-48. https://doi.org/10.1016/0007-6813(91)90005-G

Crane, A., et al.. (2014). Contesting the value of "creating shared value". California Management Review, 56(2), 130-153. https://doi.org/10.1525/cmr.2014.56.2.130

Dumay, J. (2014). Developing strategy to create a public value chain in public value management, measurement and reporting (pp. 65-83). Emerald Group Publishing Limited. https://doi.org/10.1108/S2051-663020140000003003

Ezeibe, C., Oguonu, C., Ajaero, C. K., Osadebe, N., Agbo, H., \& Uwaechia, O. (2019). From vulnerability to sustainability: Implementation of free education programmes and reversal of child trafficking in Nigeria. Journal of Human Trafficking, 1-15. https://doi.org/10.1080/23322705.2019.1647506

Ferber, T., \& White, E. (2014). Making public policy collective impact friendly. Stanford Social Innovation Review. Retrieved from https://ssir.org/articles/entry/making_public_policy_collective_impact_friendly

Friedman, M. (1970). The social responsibility of business is to increase its profits. New York: Times Magazine. 
Grönroos, C. (2011). Value co-creation in service logic: A critical analysis. Marketing Theory, 11(3), 279-301. https://doi.org/10.1177/1470593111408177

Gwynne, K., et al.. (2016). Developing a sustainable model of oral health care for disadvantaged Aboriginal people living in rural and remote communities in NSW, using collective impact methodology. Journal of Health Care for the Poor and Underserved, 27(1), 46-53. https://doi.org/10.1353/hpu.2016.0032

Hanleybrown, F., Kania, J., \& Kramer, M. (2012). Channeling change: making collective impact work. Stanford Social Innovation Review. Retrieved from https://ssir.org/articles/entry/channeling_change_making_collective_impact_work

Hänninen, H. (2012). Management of value co-creation in public service networks: case of city Helsink. Masters dissertation, Aalto University School of Economics, Helsink, Finland.

Hartley, J., Parker, S., \& Beashel, J. (2019). Leading and recognizing public value. Public Administration, 97(2), 264-278. https://doi.org/10.1111/padm.12563

Hiedemann, A. M., Nasi, G., \& Saporito, R. (2017). A public service-dominant logic for the executive education of public managers. Teaching Public Administration, 35(1), 66-87. https://doi.org/10.1177/0144739416665881

Johanson, J.-E., Pekkola, E., \& Husman, P. (2016). Government programme as a strategy-the finnish experience. Administrative Sciences, 7(2), 1-15. https://doi.org/10.3390/admsci7020016

Kania, J., \& Kramer, M. (2013). Collective impact. Standford Social Innovation Review. Retrieved from https://ssir.org/articles/entry/collective_impact

Kramer, M. R., \& Pfitzer, M. W. (2016). The ecosystem of shared value. Harvard Business Review, 94(10), 80-89.

Loeffler, E., \& Bovaird, T. (2019). Co-commissioning of public services and outcomes in the UK: Bringing co-production into the strategic commissioning cycle. Public Money \& Management, 39(4), 241-252. https://doi.org/10.1080/09540962.2019.1592905

Lombardo, R., \& D'orio, G. (2012). Corporate and state social responsibility: a long-term perspective. Modern Economy, 3(1), 91-99. https://doi.org/10.4236/me.2012.31013

Martins, S., Lunkes, R. J., Mendes, A. C. A., \& Ckagnazaroff, I. B. (2020). A influência da atuação do poder executivo na efetividade dos conselhos de direitos da população Idosa. GIGAPP Estudios Working Papers, 7(150-165), 447-468.

Mintrom, M., \& Luetjens, J. (2015). Creating public value: Tightening connections between policy design and public management. Policy Studies Journal, 45(1), 170-190. https://doi.org/10.1111/psj.12116

Moore, M. H. (1994). Public value as the focus of strategy. Australian Journal of Public Administration, 53(3), 296-303. https://doi.org/10.1111/j.1467-8500.1994.tb01467.x

Moore, M. H. (2007). Recognising public value: The challenge of measuring performance in government. In J. A. Wanna (Ed.), Passion for policy. Camberra: ANU E Press. https://doi.org/10.22459/PFP.2007.08

Moore, M. H. (2014). Public value accounting: Establishing the philosophical basis. Public Administration Review, 74(4), 465-477. https://doi.org/10.1111/puar.12198

Osborne, S. P., \& Strokosch, K. (2013). It takes two to tango? Understanding the Co-production of public services by integrating the services management and public administration perspectives. British Journal of Management, 24(1), 31-47. https://doi.org/10.1111/1467-8551.12010

Osborne, S. P., et al.. (2014). A Sustainable Business Model for Public Service Organizations?. Public Management Review, 16(2), 165-172. https://doi.org/10.1080/14719037.2013.872435

Osborne, S. P., et al.. (2015). The service framework: a public-service-dominant approach to sustainable public services. British Journal of Management, 26(3), 424-438. https://doi.org/10.1111/1467-8551.12094

Osborne, S. P., Radnor, Z., \& Nasi, G. (2013). A new theory for public service management? Toward a (public) service-dominant approach. The American Review of Public Administration, 43(2), 135-158. https://doi.org/10.1177/0275074012466935

Plagerson, S., \& Ulriksen, M. S. (2016). Can social protection address both poverty and inequality in principle and practice?. Global Social Policy, 16(2), 182-200. https://doi.org/10.1177/1468018115622521 
Porter, M. E. (1991). Towards a dynamic theory of strategy. Strategic Management Journal, 12, 95-117. https://doi.org/10.1002/smj.4250121008

Porter, M. E. (1998). Clusters and the new economics of competition. Harvard Business Review, 76(6), 77-90.

Porter, M. E., \& Kramer, M. R. (2001). Strategy and society: The link between competitive advantage and corporate social responsibility. Harvard Business Review.

Porter, M. E., \& Kramer, M. R. (2001). The competitive advantage of corporate philanthropy. Harvard Business Review, 80(12), 56-68.

Porter, M. E., et al.. (2012). Measuring shared value: How to unlock value by linking social and business results. San Francisco: FSG.

Porter, M., \& Kramer, M. (2011). Creating Shared Value. Harvard Business Review, 1-17.

Prahalad, C. K., \& Hart, S. L. (2002). The fortune at the bottom of the pyramid. Strategy + Business, 26, 1-26.

Sami, A., et al.. (2016). Role of ethical culture in creating public value. International Review of Management and Marketing, 6(4S), 255-261.

Santos, B. M. O. (2017). Crise socioambiental: compreensão e combate através de uma visão que conecte as esferas individual e coletiva. Dignidade Re-Vista, 2(3), 9.

Sotelo Maciel, A. J. (2012). La cadena de valor público: un principio ordenador que previene la colisión metodológica. Revista Internacional de Presupuesto Público, ASIP.

Takhar, S. (2015). Sustainability, human rights, and sexuality: Making the right connections. Local Economy, 30(3), 256-264. https://doi.org/10.1177/0269094215580084

Tzagkarakis, S. I., et al.. (2017). Social rights and sustainable development: a two-way street?. European Quarterly of Political Attitudes and Mentalities, 6(2), 89-100.

Ulriksen, M. S., \& Plagerson, S. (2016). The principles and practice of social protection. Global Social Policy, 16(2), 127-131. https://doi.org/10.1177/1468018116646034

Wartick, S. L., \& Cochran, P. L. (1985). The evolution of the corporate social performance model. Academy of Management Review, 10(4), 758-769. https://doi.org/10.5465/amr.1985.4279099

Wójcik, P. (2016). How creating shared value differs from corporate social responsibility. Journal of Management and Business Administration, 24(2), 32-55. https://doi.org/10.7206/jmba.ce.2450-7814.168

\section{Copyrights}

Copyright for this article is retained by the author(s), with first publication rights granted to the journal.

This is an open-access article distributed under the terms and conditions of the Creative Commons Attribution license (http://creativecommons.org/licenses/by/4.0/). 